\title{
Heavy rain prediction using deterministic and probabilistic models - the flash flood cases of 11-13 October 2005 in Catalonia (NE Spain)
}

\author{
A. Barrera, V. Altava-Ortiz, M. C. Llasat, and M. Barnolas \\ Meteorological Hazards Analysis Team (GAMA), Department of Astronomy \& Meteorology, Faculty of Physics, University \\ of Barcelona, Av. Diagonal 647, 08028 Barcelona, Spain
}

Received: 28 February 2007 - Revised: 17 June 2007 - Accepted: 17 September 2007 - Published: 21 September 2007

\begin{abstract}
Between the 11 and 13 October 2005 several flash floods were produced along the coast of Catalonia (NE Spain) due to a significant heavy rainfall event. Maximum rainfall achieved values up to $250 \mathrm{~mm}$ in $24 \mathrm{~h}$. The total amount recorded during the event in some places was close to $350 \mathrm{~mm}$. Barcelona city was also in the affected area where high rainfall intensities were registered, but just a few small floods occurred, thanks to the efficient urban drainage system of the city. Two forecasting methods have been applied in order to evaluate their capability of prediction regarding extreme events: the deterministic MM5 model and a probabilistic model based on the analogous method. The MM5 simulation allows analysing accurately the main meteorological features with a high spatial resolution $(2 \mathrm{~km})$, like the formation of some convergence lines over the region that partially explains the maximum precipitation location during the event. On the other hand, the analogous technique shows a good agreement among highest probability values and real affected areas, although a larger pluviometric rainfall database would be needed to improve the results. The comparison between the observed precipitation and from both QPF (quantitative precipitation forecast) methods shows that the analogous technique tends to underestimate the rainfall values and the MM5 simulation tends to overestimate them.
\end{abstract}

\section{Introduction}

Catalonia is located in the Northeast corner of the Iberian Peninsula. The orography of the country is very complex, and it has a strong influence on pluviometry. Therefore, remarkable contrasts are observed in a few kilometres. Three mountain ranges are the most important geographical factors

Correspondence to: A. Barrera

(tbarrera@am.ub.es) influencing meteorological processes: The Littoral range, the Pre-littoral barrier and the Pyrenees in an increasing altitudinal order. They have an important role on pluviometric events enhancement (Llasat et al., 1999).

Catalonia has been periodically affected by heavy rainfall events during the last years. These events occur mainly in autumn, which is the rainiest season in the region. Recent examples of such type of events are the cases of 9-10 June 2000 (Llasat et al., 2003), 21-24 October 2000 (Barnolas, 2004), 8-10 October 2002 (Llasat et al., 2004), 16-18 October 2003 (Altava-Ortiz et al., 2006) and 6 September 2004. As a result of the heavy rainfall frequency in Catalonia, flash floods are usually recorded in the coastal little basins with a strong slope towards to sea. For example the city of Barcelona has been affected by 54 flash floods since 1351 ( $\sim 1$ flash flood per 10 years) (Barrera et al., 2006).

Statistical and deterministic methods are applied in the current paper, to analyse how they work when an extreme rainfall event is registered. A first dual treatment (deterministic-statistical) for extreme cases was performed in Altava-Ortiz et al. (2006). Here, more detailed probabilistic outputs in addition to new MM5 simulations have been developed and applied to one of the last heavy rainfall events registered in Catalonia: the 11-13 October 2005 event.

\section{Meteorological situation and event overview}

On 11 October 2005 a strong anticyclone was located over Eastern Russia producing a high pressure blocking. At the same time, a trough was formed in front of the Portugal coast. Due to the blocking, forced by the high pressure centre, this trough moved towards the South-East during the following days, reaching the centre of Iberian Peninsula in the form of a very well-defined cut-off low on 13 October at 12:00 UTC. This configuration implied an important advection of warm and moist air masses against the littoral and

Published by Copernicus Publications on behalf of the European Geosciences Union. 

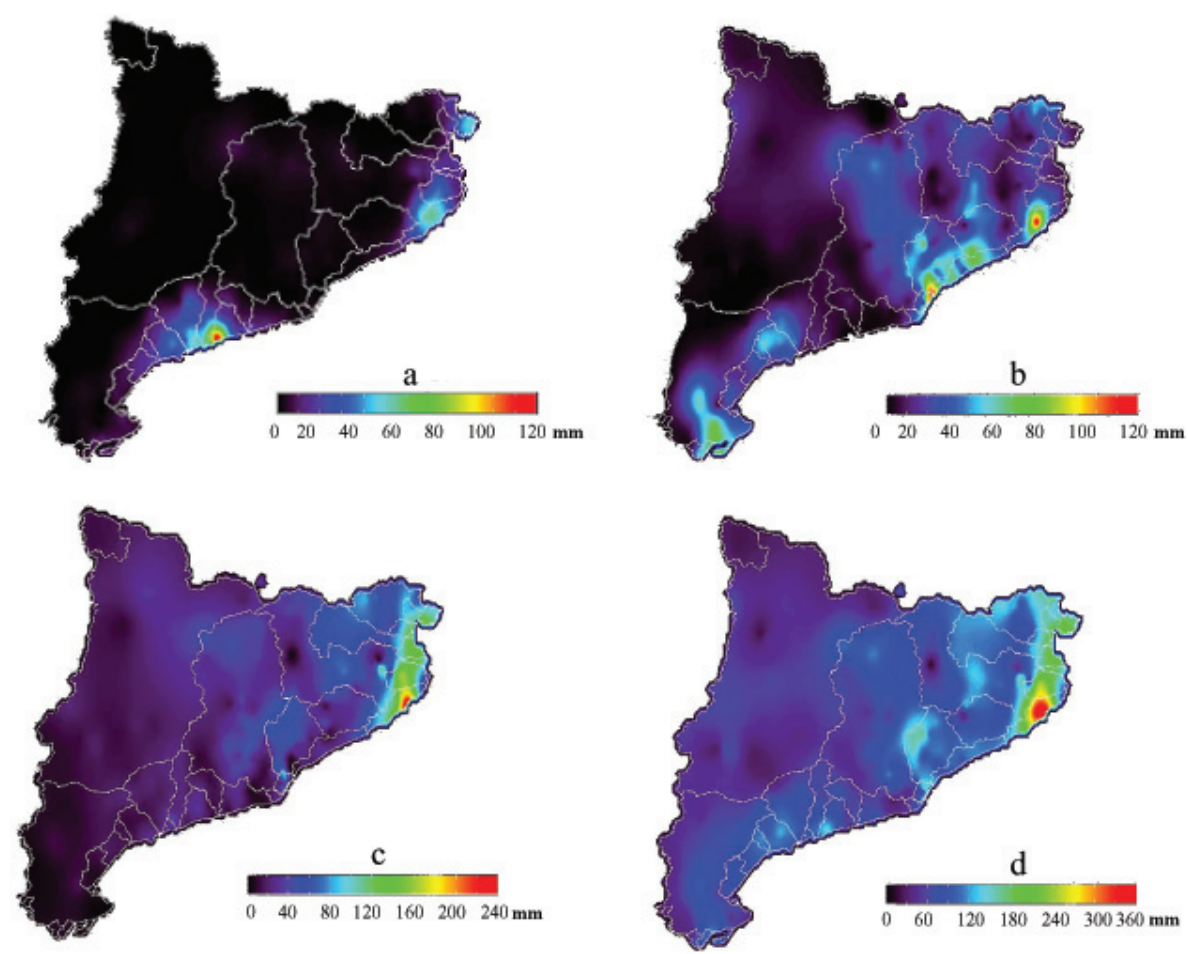

Fig. 1. Recorded precipitation from 00:00 to 24:00 UTC over Catalonia on 11 October 2005 (a), 12 October 2005 (b), 13 October 2005 (c) and total accumulated precipitation from 11 October 2005 at 00:00 UTC to 16 October 2005 at 00:00 UTC (d). Data obtained from 313 stations.

pre-littoral ranges of Catalonia at low levels. At surface an important low was installed over the centre of the Iberian peninsula during the event and produced a southern wind flux against Catalonia. As a result, heavy precipitations and flash floods were recorded during the event resulting in 4 casualties and several material damages. This event had similar characteristics to the September 1971 event (Llasat et al., 2007), but it has been less damaging and catastrophic.

Figure 1 shows the rainfall evolution of the entire episode, from 11 to 13 October and also the total amount recorded. The event began on 11 October with heavy rainfalls over the central southern Catalan coast. The Creixell ephemeral river was overflowed (Fig. 2a), producing an important flash flood in that locality, due to an amount of precipitation of $134 \mathrm{~mm}$ in few hours (Fig. 1a). The next day (12 October, Fig. 1b) the instability moved northwards and heavy rainfall was recorded over Barcelona city, its metropolitan area and central northern Catalan coast. The third day (13 October, Fig. 1c) the heaviest rainfalls occurred in the Northern coastal region with maximum daily precipitation amounts up to $250 \mathrm{~mm}$ and 5 -min intensities close to $100 \mathrm{~mm} / \mathrm{h}$ (Fig. 3). As a result, a large number of ephemeral rivers were overflowed and flash floods were produced (catastrophic damages in Calonge ephemeral river, Fig. 2a). The Daró and Ridaura rivers were also within the affected catchments (Fig. 2a). During the 14-15 October the rainfall continued, but with a more moderate intensity without any flash flood recorded. As a summary, more than $340 \mathrm{~mm}$ in the entire episode were recorded in some places of the north Catalan coast (Fig. 1d).

Figure $2 \mathrm{a}$ shows the municipalities affected by flash floods, while Fig. $2 b$ presents the affected basins. The affected basins have areas between 90 and $340 \mathrm{~km}^{2}$ (Fig. 2b), short response time and are periodically affected by flash floods. For example the Maresme basin (Fig. 2b) has been affected by 131 flash floods during the 20th century $(\sim 1.3$ flash floods per year) (Barnolas and Llasat, 2007). Concerning material losses, approximately 4000 houses, more than 3000 shops, and 1500 cars were damaged in the municipalities of Platja d'Aro, Santa Cristina d'Aro, Calonge and Sant Feliu de Guíxols. There were other damages in infrastructures and public ownerships. All these damages were evaluated in more than 21 million euros (economic losses in public infrastructures rose above 6 million euros in Santa Cristina d'Aro). Between 8000 and 10000 claims were received by the Spanish National Consortium of Insurances (Consorcio de Compensación de Seguros). However, the counting is difficult because some claims were made through private insurance companies. 


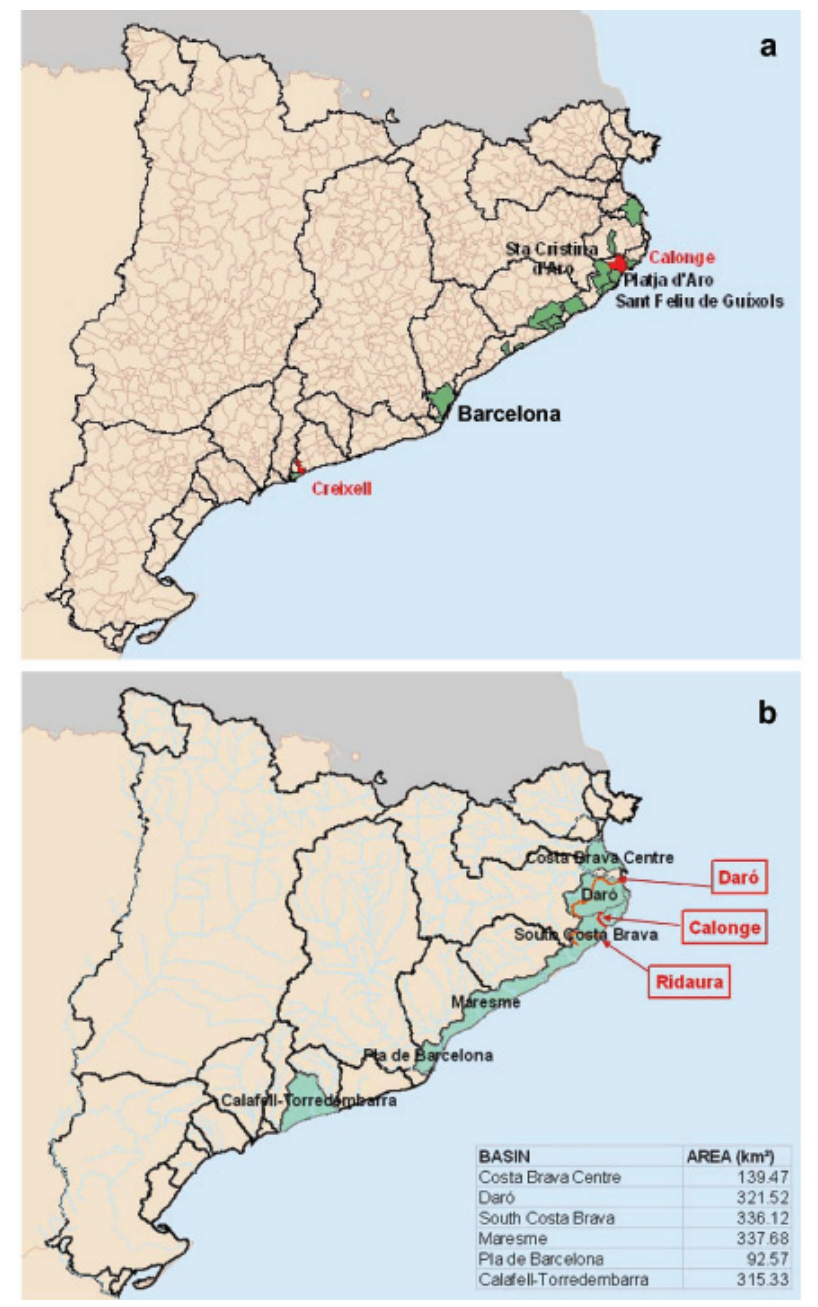

Fig. 2. (a) Municipalities affected by flash floods. In red are shown the municipalities with catastrophic flooding. (b) Affected basins: location and area.

\section{Data and methodology}

Different sources of data have been used for developing the present study. To develop the observed daily rainfall charts 313 rainfall stations has been compiled within Catalonia and surroundings areas (Fig. 4). The data used in the analogous technique and for the MM5 model simulations are detailed as follows.

\subsection{Analogous method}

The analogous method applied here is a statistical downscaling method using the geopotential height at $1000 \mathrm{hPa}$, $850 \mathrm{hPa}$ and $500 \mathrm{hPa}$ as primary predictor fields, and the geopotential height and humidity at $1000 \mathrm{hPa}$ as secondary predictor fields. The method estimates the probability of exceeding a certain rainfall value in $24 \mathrm{~h}$, according to an ensemble of rainfall patterns that occurred in the past, by

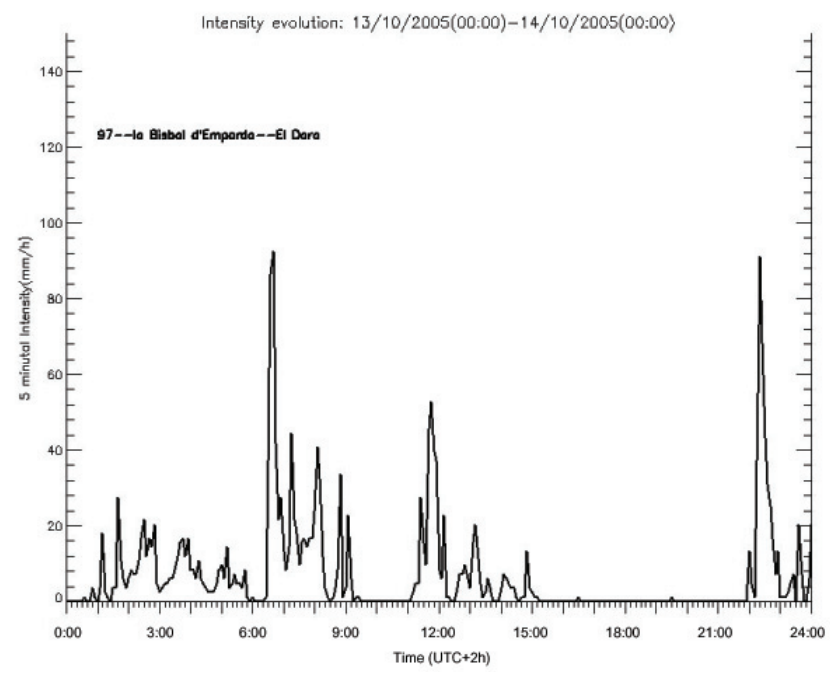

Fig. 3. Hyetogram for La Bisbal d'Empordà showing the high 5min rainfall intensities reached during the 13 October 2005.

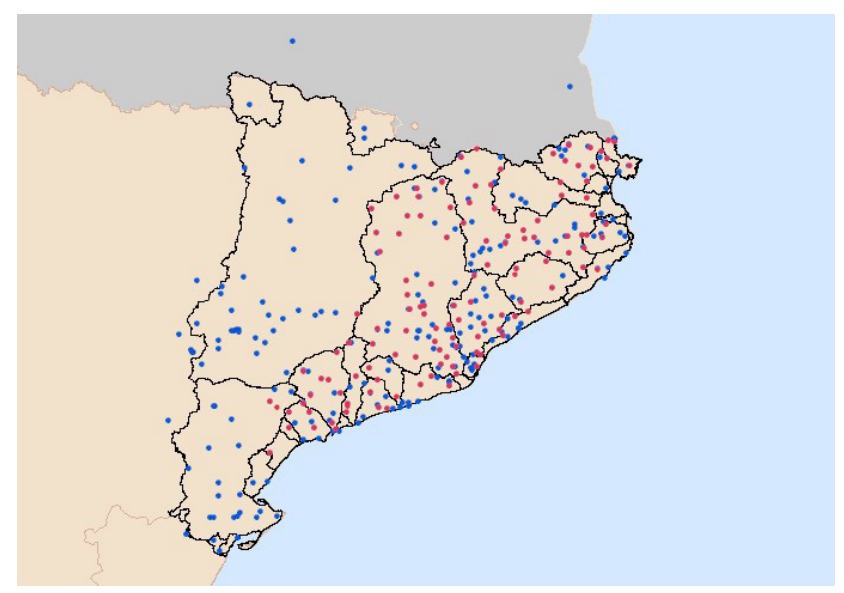

Fig. 4. Distribution of the 313 rainfall stations used in the present work. Red dots are the stations used in the analogous methods and blue ones are the other stations used for developing observed rainfall charts.

means of establishing statistical relations among past and forecast meteorological situations. The pressure data values are provided by the NCEP-NCAR Reanalysis Project (NNRP). The rainfall database has good coverage over East Catalonia (Fig. 4) with more than 120 stations for an area of $16000 \mathrm{~km}^{2}$ and for the period 1996-2005. This is the period used for the development of the analogous model. For further details of the applied analogous model see Altava-Ortiz et al. (2006).

Probabilistic outputs are calculated taking into account the best 20 meteorological analogous situations. The interpolation (using the kriging procedure) is carried out at $0.04^{\circ} \times 0.04^{\circ}$ of grid resolution. Probability of exceedance (ERP) $0.5 \mathrm{~mm}, 2 \mathrm{~mm}, 10 \mathrm{~mm}$ and $20 \mathrm{~mm}$ in $24 \mathrm{~h}$ in addition 


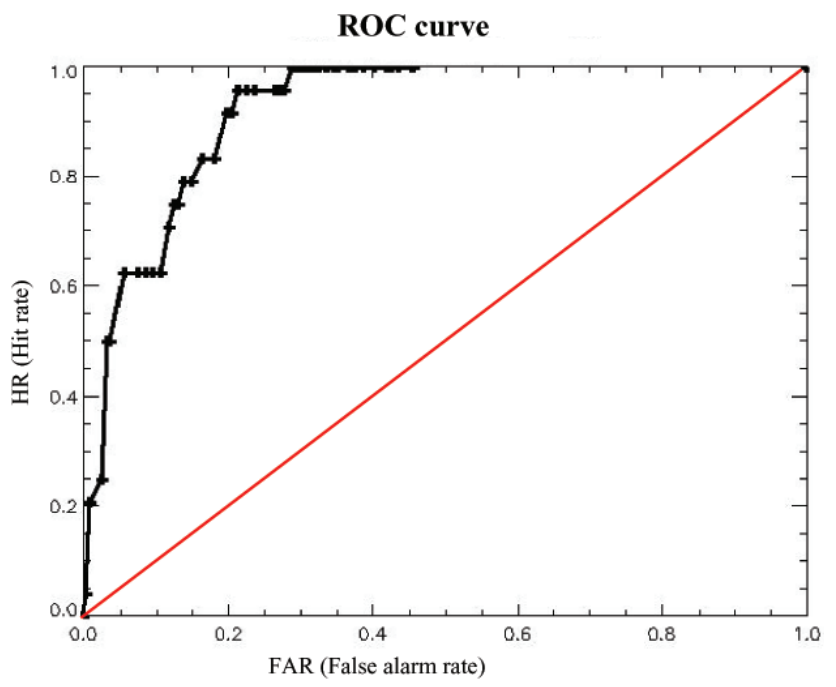

Fig. 5. ROC curve for the highest threshold (precipitation $>20 \mathrm{~mm}$ in $24 \mathrm{~h}$ ) in the statistical analogous method. HR is the hit rates and FAR represents the false alarm rate.

to Average Expected rainfall (AER) and Maximum Expected rainfall (MER) values for each day in the analysed episode have been calculated.

The results obtained in the recently finished INTERREG III-B AMPHORE project $^{1}$ showed that this method is a good statistical prediction tool. Model reliability has been performed using Receiver Operating Characteristic Curves (ROC curves). A ROC curve for each considered threshold as well as for each station forming the surface rainfall network has been calculated. The most interesting result for the current paper is the ROC curve corresponding to the highest rainfall threshold (Fig. 5). This ROC curve was obtained from averaging the 126 ROC curves associated to each raingauge of the observation network for the entire 1996 year, a very rainy year in Catalonia. The greater the area under the curve, the better is the model. A value around 0.95 has been obtained for the $20 \mathrm{~mm}$ exceedance rainfall.

\subsection{The MM5 model}

The MM5 mesoscale model (Grell et al., 1994; Dudhia et al., 2004) is one of the most widely used models by the scientific community. This numerical model has been run for a $72 \mathrm{~h}$ simulation starting at 00:00 UTC from 11 to 14 October 2005. Four two-way nested domains with 54, 18, 6 and $2 \mathrm{~km}$ horizontal grid resolution and 23 vertical levels have been used. The outer domain (domain 1) is centred in the $\mathrm{NE}$ Spain at geographical coordinate $\left(0.0^{\circ} \mathrm{E}, 40.0^{\circ} \mathrm{N}\right)$. Initial and boundary conditions are obtained from the $1^{\circ}$ resolution FNL NCEP analyses (Global Final Analyses from the

\footnotetext{
${ }^{1}$ Information concerning AMPHORE project is availabe within http://amphore.medocc.org/.
}

US National Centers for Environmental Prediction) available every six hour from 00:00 UTC, which are improved using surface and upper-air observations (ADP, Automated Data Processing observations from the NCEP). This improvement is applied by an objective analysis tool included in the program scheme of the MM5 model. Full physics is used and a Kain-Fritsch (Kain and Fritsch, 1993) scheme is applied to parameterise convection for the first, second and third domains while no convective parameterisation is activated over the fourth domain. Similar parameterisation has been used with good results in other similar extreme meteorological events in the West Mediterranean area (Arreola et al., 2003; Romero et al., 2005).

\section{Results and discussion}

Figure 6 shows the probability of exceeding 0.5 and $20 \mathrm{~mm}$ in $24 \mathrm{~h}$ as well as MER on 11 and 13 October, as derived from the analogous method. In general, good agreement among highest probability values and real affected areas can be observed. Moreover, in some days, MER distribution shows good agreement with the observed rainfall patterns, although values are usually underestimated. The 11 October is an exception, when the analogous method overestimates them. At this point it should be taken into account that this event was characterised by very heavy rainfall, such events are quite infrequent and thus it is more difficult for the analogous method to reproduce them. In addition in order to further improve the method a much denser pluviometric network is needed.

The MM5 simulation allows analysing accurately the main meteorological features with high spatial resolution. The evolution of the $10-\mathrm{m}$ wind field for the 2-km domain shows the formation of different convergence lines at different places of the region. This partially explains the location of rainfall maxima during the event (not shown). These convergence lines enhanced the triggering effects of the ranges close to the sea, facilitated the advection of moist air over those zones and implied high values of potential temperature at medium levels $(850 \mathrm{hPa})$. The eastern parts of the Pyrenees and the Pre-Littoral range plays an important role on the enhancement of precipitation, as in the simulations and observations, all main maxima are recorded in those zones (Fig. 7). In addition, the high spatial resolution used for the MM5 simulations permitted to reproduce the maxima of accumulated rainfall quantities, but their locations are not wellplaced (Fig. 7).

With the MM5 outputs, in addition to the analogous method ones, and taking into account the event observations some conclusions appear clearly:

i) Both methods, probabilistic and deterministic, get quite reasonable rainfall forecasts or probability distribution if they are compared with the observations, although 


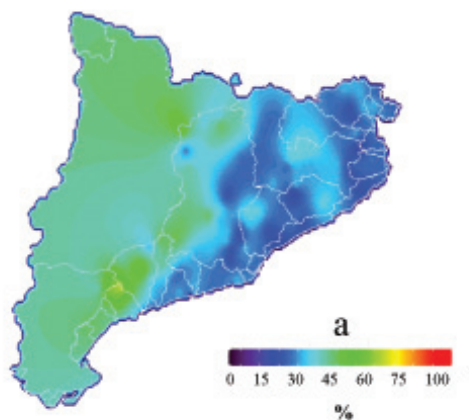

$\%$

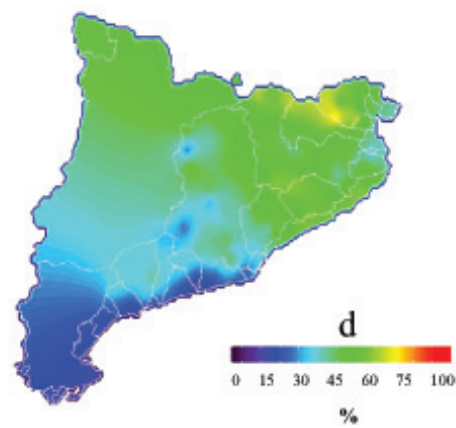

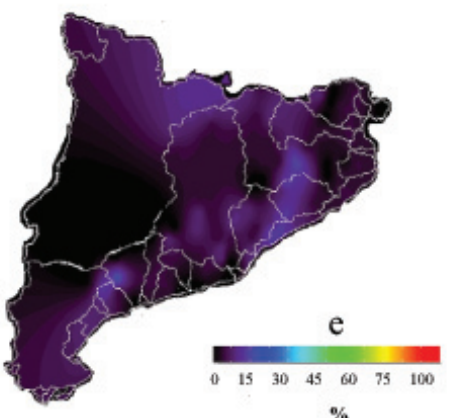

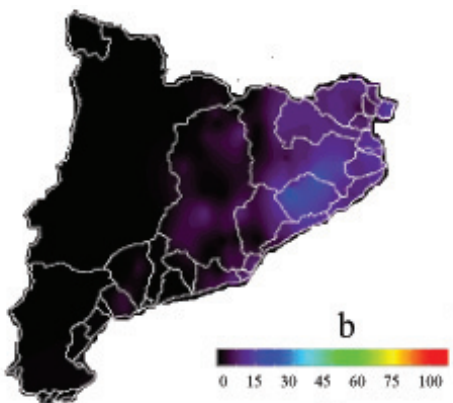

$\%$

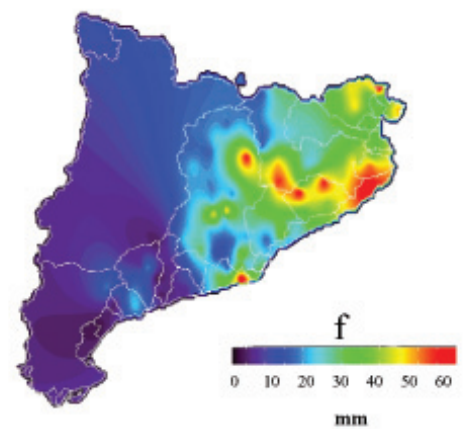

Fig. 6. Probabilistic outputs for the lowest (a and d) and highest (b and e) rainfall thresholds as well as the MER (on 11 October 2005 from 00:00 to 24:00 UTC (upper figures) and on 13 October 2005 from 00:00 to 24:00 UTC (lower figures).

some important disagreements (an important overestimation) appear in SW Catalonia.

ii) Whereas the analogous technique tends to underestimate the values on rainfall, the MM5 simulation tends to misplace the maxima.

Comparing with the results obtained in the previous work of Altava-Ortiz et al. (2006) other conclusions appear clearly. The analogous model continues underestimating the rainfall field, but the location of maxima is correct.

The analogous method is a first approach, less suitable than deterministic models for the prediction of heavy rainfall events as statistical models are based on previous events, and extreme events are not so common. However, probabilistic outputs from the statistical model combined with the MM5 model outputs provide different products which could be complementary and useful for end-users. The MM5 model output provides a good simulation of the evolution of important meteorological variables and the analogous technique offers good outputs concerning rainfall probabilities and MER but mainly better localisation of the rainfall maxima compared to MM5 model output.

On the other hand, to improve the observed disagreements, future work is needed in both methods. The MM5 model results could be improved by improving the initial conditions. This could be achieved by using higher resolution initial conditions and by improving the first guess fields using lightning and satellite data as it will be done in the European project FLASH. The analogous technique needs a longer tempo- ral daily rainfall database with a good coverage in the region, and the proof of other effective predictor meteorological fields.

Acknowledgements. The authors thank the Sixth Framework Programme European Commission FLASH project (FTS-2005global-036852) and the European INTERREG III-B AMPHORE project (2003-03-4.3-I-079) for making possible the development of the present work. The authors also thank Meteocat (Catalan Meteorological Service) for its rainfall data and the ACA (Catalan Agency of Water) for the rainfall data from the SAIH network.

Edited by: P. Alpert, H. Saaroni, and E. Heifetz

Reviewed by: two anonymous referees

\section{References}

Altava-Ortiz, V., Barrera, A., Llasat, M. C., Prat, M. A., GibergansBáguena, J., and Barnolas, M.: Application of the MM5 and the analogous method to heavy rainfall events. The case of 16-18th October 2003 in Catalonia (NE Spain), Adv. Geosci., 7, 313319, 2006,

http://www.adv-geosci.net/7/313/2006/.

Arreola, J. L., Homar, V., Romero, R., Ramis, C., and Alonso, S.: Multiscale numerical study of the 10-12 November 2001 strong cyclogenesis event in the western Mediterranean, Proceedings of the 4th EGS Plinius Conference on Mediterranean Storms, Alcudia (Spain), 2-4 October 2002, CD-Rom, Sec. 1, 30, 2003.

Barnolas Viladés, M.: Desarrollo de un sistema ACCESS/SIG en el ámbito de las ciencias de la atmósfera: Estudio de las inundaciones en Catalunya, 1901-2000. Trabajo para la ob- 

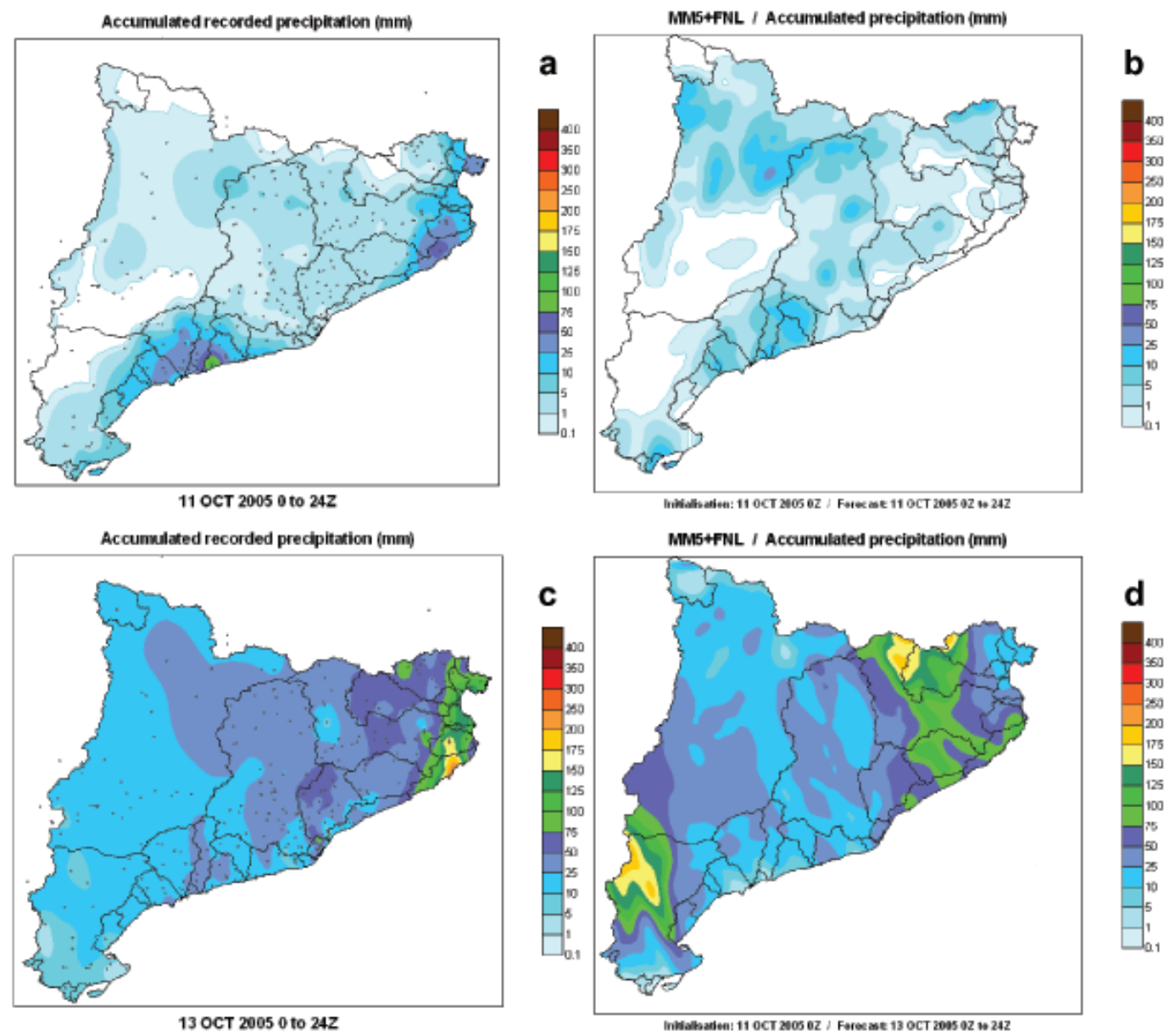

Fig. 7. Comparison between observed (a and $\mathbf{c}$ ) and 2-km resolution MM5 forecasts (b and d) for accumulated daily rainfall for 11 October 2005 from 00:00 to 24:00 UTC (upper figures) and for 13 October 2005 from 00:00 to 24:00 UTC.

tención del Diploma de Estudios Avanzados (DEA), Programa de doctorado de Astronomía y Meteorología (Bienio 2002-2004). DAM/250201-05/0409, Internal publication, 2004.

Barnolas, M. and Llasat, M. C.: A flood geodatabase and its climatological applications: the case of Catalonia for the last century, Nat. Hazards Earth Syst. Sci., 7, 271-281, 2007, http://www.nat-hazards-earth-syst-sci.net/7/271/2007/.

Barrera, A., Llasat, M. C., and Barriendos, M.: Estimation of the extreme flash flood evolution in Barcelona County from 1351 to 2005, Nat. Hazards Earth Syst. Sci., 6, 505-518, 2006, http://www.nat-hazards-earth-syst-sci.net/6/505/2006/.

Dudhia, J., Gill, D., Manning, K., Wang, W., and Bruyere, C.: PSU/NCAR Mesoscale modeling system. Tutorial Class Notes and User's Guide: MM5 Modeling System Version 3, www. mmm.ucar.edu/mm5/documents/tutorial-v3-notes.html, 2004.

Grell, G. A., Dudhia, J., and Stauffer, D. R.: A description of the fifth-generation Penn State/NCAR mesoscale model (MM5), NCAR Technical Note, NCAR/TN-398+STR, 1994.

Kain, J. S. and Fritsch, J. M.: Convective parameterization for mesoscale models: The Kain-Fritsch scheme, in: The representation of cumulus convection in numerical models, edited by: Emanuel, K. A. and Raymond, D. J., Meteorological Monograph of the American Meteororological Society, 46, 165-170, 1993.
Llasat, M. C., Martín, F., and Barrera, A.: From the concept of "kaltluftropfen" (cold air pool) to the cut-off low. The case of September 1971 in Spain as an example of their role in heavy rainfalls, Meteorol. Atmos. Phys., 96, 43-60, 2007.

Llasat, M. C., Rigo T., and Barriendos, M.: The "Montserrat-2000" flash flood event: a comparison with the floods that have occurred in the northeastern Iberian Peninsula since the 14th century, Int. J. Climatol., 23, 453-469, 2003.

Llasat, M. C., Rigo, T., and Montes, J. M.: Orographic role in the temporal and spatial distribution of precipitation in flood events, Proceedings of the 1st EGS Plinius Conference on Mediterranean Storms, Maratea (Italy), 14-16 October 1999, 41-55, 1999.

Llasat, M. C.: La vulnérabilité en Catalogne et la perception sociale, La Houille Blanche, 6, 71-75, 2004.

Romero, R., Martín, A., Homar, V., Alonso, S., and Ramis, C.: Predictability of prototype flash flood events in the Western Mediterranean under uncertainties of the precursor upper-level disturbance: the HYDROPTIMET case studies, Nat. Hazards Earth Syst. Sci., 5, 505-525, 2005, http://www.nat-hazards-earth-syst-sci.net/5/505/2005/. 